\title{
GROWTH PERFORMANCE, CARCASS CHARACTERISTICS, MEAT QUALITY OF GROWING PIGS FED DIETS SUPPLEMENTED WITH CRUDE GLYCERIN DERIVED FROM PALM OIL
}

\author{
DESEMPENHO PRODUTIVO, CARACTERÍSTICAS DE CARCAÇA \\ QUALIDADE DA CARNE DE SUÍNOS EM CRESCIMENTO ALIMENTADOS \\ COM DIETAS INCLUINDO GLICERINA BRUTA DERIVADA DE ÓLEO DE \\ PALMA
}

\author{
Ciro Ordoñez-Gomez ${ }^{1 *}$ \\ German Afanador-Tellez ${ }^{2}$ \\ Sandra Castañeda ${ }^{3}$ \\ Hernando Florez $z^{3}$ \\ Claudia Ariza-Nieto ${ }^{3}$ \\ 'Universidad Francisco de Paula Santander-Ocaña, Ocaña, Norte de Santander, Colombia. \\ ¿Universidad Nacional de Colombia, Bogotá, Colombia. \\ ${ }^{3}$ Corporacion Colombiana de Investigacion Agropecuaria, Bogotá, Colombia. \\ *Author for correspondence - caordonezg@ufpso.edu.co
}

\begin{abstract}
The aim of this study was to evaluate the effect of the inclusion level of crude glycerin from palm oil in the diet of growing pigs. Diets were formulated to be isocaloric and isoproteic, with a constant content of linoleic acid within the experimental diets. A total of 36 pigs (average BW 23.05 2.86 $\mathrm{kg}$ ) were randomly assigned to one of the three treatments: 1) $0 \%$ of crude glycerin; 2) $5 \%$ of crude glycerin; 3) $10 \%$ of crude glycerin. Pigs were housed in 12 pens; 4 replicates (pens) per treatment and three pigs/replicate. Data were analyzed as a complete block design using the GLIMMIX procedure of SAS, with a random block effect for period. This study established that inclusion of crude glycerin from palm oil in the diet of growing pigs did not affect $(\mathrm{P}>0.05)$ growth performance, carcass characteristics and meat quality. We concluded that inclusion of crude glycerin from palm oil up to $10 \%$ of the diet did not adversely affect pig performance and the quality of the meat.
\end{abstract}

Keywords: biodiesel; by-products; palm oil; swine.

\section{Resumo}

O objetivo deste estudo foi avaliar o efeito da inclusão de níveis de glicerina bruta do óleo de palma na dieta de suínos em crescimento. As dietas foram formuladas para serem isoenergéticas e 
isoproteicas, o teor de ácido linoléico permaneceu constante na dieta. No total, 36 suinos (com média $\mathrm{BW}$ de 23,05 $\pm 2,86 \mathrm{~kg}$ ) foram distribuídos aleatoriamente em três tratamentos: 1) $0 \%$ de glicerina bruta; 2) 5\% de glicerina bruta; 3) 10\% de glicerina bruta. Os leitões foram alojados em 12 baias com quatro repetições (baias) por tratamento, três suínos/repetição. Os dados foram analisados como um delineamento em blocos casualizados utilizando-se o procedimento GLIMMIX do SAS, com um efeito aleatório de bloco por período. Notou-se que a inclusão de glicerina bruta do óleo de palma não afetou $(\mathrm{P}>0,05)$ o desempenho produtivo, as características da carcaça e qualidade da carne. Concluiu-se que a inclusão de glicerina bruta do óleo de palma até $10 \%$ não afetou o desempenho dos suínos e a qualidade da carne.

Palavras-chave: biodiesel; óleo de palma; subprodutos; suínos.

Received on: April 14 ${ }^{\text {th }}, 2016$

Accepted on: November, $24^{\text {th }}, 2016$

\section{Introduction}

The biodiesel industry from fatty sources generates glycerin, a by-product that can be used as an excellent source of energy for growing pigs. In Colombia, the installed capacity of biodiesel production was of $505.708 \mathrm{t}$ in $2013^{(1)}$. Each liter of biodiesel generates approximately $79 \mathrm{~g}$ of

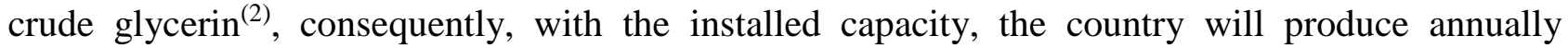
around of $51940 \mathrm{t}$ of crude glycerin $\left(80 \%\right.$ glycerol) with a density of $1.3 \mathrm{~g} / \mathrm{ml}^{(3)}$.

In pigs, crude glycerin obtained from soybean oil has shown an energy value close to corn ${ }^{(4,5)}$. Several studies have revealed that the inclusion of crude glycerin up to $16 \%$ in isoenergetic and isoproteic diets for pigs has not affected performance, carcass characteristics and meat quality ${ }^{(2,6-10)}$. However, when corn was replaced by crude glycerin as the source of dietary fatty acids (FA), a reduction in the content of polyunsaturated fatty acids in the loin occurred ${ }^{(2)}$. Regarding the case of crude glycerin from palm oil, no studies on the evaluation of its effect on the performance of pigs.

This study evaluated the effect of the inclusion level of crude glycerin from palm oil (PO) in the diet of growing pigs on growth performance, carcass characteristics, and meat quality.

\section{Material and Methods}

The Bioethics Committee of the Faculty of Veterinary Medicine of the National University of Colombia (UN) approved all the procedures involving animals in this study (Act 4 of September 28, 2011). This study was developed in the swine section of the Agricultural Center "MARENGO" of the UN-Bogota. A total of 36 pigs of a commercial crossing (Yorkshire x Landrace $\mathrm{x}$ Pietrain, 
average $\mathrm{LW}$ of $23.05 \pm 2.86 \mathrm{~kg}$ ) were randomly assigned to pens with three pigs per pen and four pens (replicates) per treatment. Dietary treatments were assigned in a completely randomized block design as follows: 1) control - 0\% crude glycerin; 2) 5\% crude glycerin; 3) 10\% crude glycerin from PO. Crude glycerin from PO was obtained from a biodiesel production facility (Bio-D S.A, Facatativa, Colombia). Table 1 displays the chemical composition of crude glycerin from PO. The maximum level of inclusion of CG was $10 \%$ because it is the level that has not affected the performance of pigs using other sources of crude glycerin ${ }^{(2,6,7,9,10)}$, although in Australia the use of up to $16 \%$ of $\mathrm{CG}$ did not affect the performance of animals but there were difficulties in feed management ${ }^{(8)}$.

Table 1. Characteristics of crude glycerin from PO

\begin{tabular}{lc}
\hline Item & Value $^{1}$ \\
\hline Moisture, \% & 8.29 \\
$\mathrm{GE}^{2}, \mathrm{kcal} / \mathrm{kg}$ & 3696 \\
Glycerol, \% & 82 \\
Crude fat, \% & 0.79 \\
$\mathrm{Na}, \%$ & 1.21 \\
Methanol, ppm & 16 \\
\hline${ }^{1}$ Analysis by CORPOICA-CBB, Mosquera, Colombia, adjusted to the methods utilized by Dozier et al. \\
${ }^{(11)}$
\end{tabular}

Diets were formulated to be isocaloric and isoproteic according to the method used by Araújo et al. ${ }^{(12)}$. Pigs were fed diets over a 4-phase feeding program, within each phase diets were offered ad libitum in meal form. Pigs in each pen were weighed weekly, and feed residuals were used to calculate weekly feed intake and feed conversion. Consumption was corrected for the number of animals $^{(2)}$. The day before slaughter $(100 \mathrm{~kg} \mathrm{BW})$, a pig with average weight within replicates was selected. The feed was removed but water was maintained in the pen ${ }^{(3,9)}$.

Feeding phases were from 20-30 kg, 30-50 kg, 50-70 kg, and 70-100 kg LW. Experimental diets are shown in Table 2. Previous results have shown the effect of crude glycerin on the fatty acid profile of pork loin ${ }^{(2)}$; therefore, the level of linolenic acid in the diet was monitored and kept constant by using as diet ingredients palm oil and full-fat soybean. 
Table 2. Description of experimental diets

\begin{tabular}{|c|c|c|c|c|c|c|c|c|c|c|c|c|c|}
\hline \multirow{3}{*}{ Ingredient } & \multirow{3}{*}{$\begin{array}{l}\text { Cost. } \\
\text { S/kg }\end{array}$} & \multirow{2}{*}{\multicolumn{3}{|c|}{$\begin{array}{c}\text { Phase I } \\
(20-30 \mathrm{~kg})\end{array}$}} & \multicolumn{3}{|c|}{$\begin{array}{c}\text { Phase II } \\
(30-50 \mathrm{~kg})\end{array}$} & \multicolumn{3}{|c|}{$\begin{array}{l}\text { Phase III } \\
(50-70 \mathrm{~kg})\end{array}$} & \multicolumn{3}{|c|}{$\begin{array}{c}\text { Phase IV } \\
(70-100 \mathrm{~kg})\end{array}$} \\
\hline & & & & & \multicolumn{6}{|c|}{ Crude glycerin level } & \multirow[b]{2}{*}{$\mathbf{0}$} & \multirow[b]{2}{*}{5} & \multirow[b]{2}{*}{10} \\
\hline & & $\mathbf{0}$ & 5 & 10 & $\mathbf{0}$ & 5 & 10 & 0 & 5 & 10 & & & \\
\hline Corn, \% & 790 & 55.5 & 50 & 44 & 54 & 48 & 42 & 55 & 49 & 43 & 58 & 52 & 46 \\
\hline Wheat bran, \% & 550 & 6 & 6 & 6 & 12 & 12 & 12 & 12 & 12 & 12 & 12 & 12 & 12 \\
\hline Rice bran, \% & 720 & 8 & 8 & 8 & 8 & 8 & 8 & 10 & 10 & 10 & 10 & 10 & 10 \\
\hline Full-fat soybean, $\%$ & 1240 & & & & 0.3 & 2.8 & 5.2 & 0.3 & 2.7 & 5.2 & 0.2 & 2.7 & 5.2 \\
\hline Soybean meal, \% & 1080 & 25 & 26 & 27 & 20 & 20 & 19 & 18 & 17 & 16 & 15 & 14 & 13 \\
\hline Palm oil, \% & 2000 & 2 & 2 & 2 & 3 & 2 & 1 & 3 & 2 & 1 & 3 & 2 & 1 \\
\hline Crude glycerin, \% & 800 & 0 & 5 & 10 & 0 & 5 & 10 & 0 & 5 & 10 & 0 & 5 & 10 \\
\hline Salt, \% & 205 & 0.4 & 0.4 & 0.4 & 0.4 & 0.4 & 0.4 & 0.4 & 0.4 & 0.4 & 0.4 & 0.4 & 0.4 \\
\hline \multicolumn{14}{|l|}{ Sodium bicarbonate; } \\
\hline$\%$ & 2500 & 0.4 & 0.3 & 0.3 & 0.4 & 0.4 & 0.3 & 0.5 & 0.4 & 0.4 & 0.6 & 0.6 & 0.5 \\
\hline Limestone, \% & 140 & 0.9 & 0.8 & 0.8 & 0.8 & 0.8 & 0.8 & 0.7 & 0.7 & 0.7 & 0.7 & 0.7 & 0.6 \\
\hline $\begin{array}{l}\text { Dicalcium phosphate, } \\
\%\end{array}$ & 2450 & 1.0 & 1.0 & 1.0 & 0.8 & 0.8 & 0.8 & 0.5 & 0.5 & 0.6 & 0.4 & 0.4 & 0.5 \\
\hline DL-methionine & 12000 & 0.01 & 0.01 & 0.01 & 0.01 & 0.01 & 0.01 & 0.01 & 0.01 & 0.01 & & & \\
\hline L-lysine & 4500 & 0.04 & 0.02 & 0.00 & 0.06 & 0.04 & 0.02 & 0.06 & 0.04 & 0.02 & 0.05 & 0.03 & \\
\hline L-threonine & 6800 & 0.1 & 0.1 & 0.1 & & & & & & & & & \\
\hline Choline chloride, $\%$ & 2782 & 0.1 & 0.1 & 0.1 & & & & & & & & & \\
\hline Premix $^{1}, \%$ & 20000 & 0.7 & 0.7 & 0.7 & 0.3 & 0.3 & 0.3 & 0.3 & 0.3 & 0.3 & 0.3 & 0.3 & 0.3 \\
\hline Total & & 100 & 100 & 100 & 100 & 100 & 100 & 100 & 100 & 100 & 100 & 100 & 100 \\
\hline \multicolumn{14}{|c|}{ Calculated composition } \\
\hline $\mathrm{ME}, \mathrm{Mcal} / \mathrm{kg}$ & & 3.2 & 3.2 & 3.2 & 3.2 & 3.2 & 3.2 & 3.2 & 3.2 & 3.2 & 3.2 & 3.2 & 3.2 \\
\hline $\mathrm{CP}, \%$ & & 19 & 19 & 19 & 18 & 18 & 18 & 17 & 17 & 17 & 16 & 16 & 16 \\
\hline Digestible Lysine, \% & & 0.9 & 0.9 & 0.9 & 0.8 & 0.8 & 0.8 & 0.7 & 0.7 & 0.7 & 0.7 & 0.7 & 0.7 \\
\hline $\begin{array}{l}\text { Available } \\
\text { phosphorus; } \%\end{array}$ & & 0.3 & 0.3 & 0.3 & 0.3 & 0.3 & 0.3 & 0.2 & 0.2 & 0.2 & 0.2 & 0.2 & 0.2 \\
\hline Linoleic acid, \% & & 2.0 & 1.8 & 1.7 & 2.1 & 2.1 & 2.1 & 2.2 & 2.2 & 2.2 & 2.2 & 2.2 & 2.2 \\
\hline Starch, \% & & 39 & 36 & 32 & 40 & 36 & 33 & 41 & 37 & 34 & 43 & 39 & 36 \\
\hline $\mathrm{EB}^{2}, \mathrm{meq} / \mathrm{kg}$ & & 250 & 250 & 250 & 250 & 250 & 250 & 250 & 250 & 250 & 250 & 250 & 250 \\
\hline
\end{tabular}

\footnotetext{
${ }^{1}$ Provided the following per kilogram of diet: Vitamin B6, $3 \mathrm{mg}$; Vitamin B12, $0.03 \mathrm{mg}$; Niacin, $30 \mathrm{mg}$; Pantothenic acid, $20 \mathrm{mg}$; Fitic acid, $15 \mathrm{mg}$; Biotine, $0.25 \mathrm{mg}$; Cu, $15 \mathrm{mg}$; Fe, $80 \mathrm{mg}$; Mn, $40 \mathrm{mg}$; I, $1 \mathrm{mg}$; $\mathrm{Zn}, 100 \mathrm{mg}$; Se, $0.3 \mathrm{mg}$.

${ }^{2}$ Electrolitic balance
}

Pigs were slaughtered in a commercial plant. Hot carcasses were weighed $(\mathrm{HCW})$ and refrigerated overnight at $0{ }^{\circ} \mathrm{C}$, and lean meat yield (LMY) was calculated according to the methods described by the following equation developed in Colombia ${ }^{(13)}$.

$$
\mathrm{LMY}=3872+(-0.3344 * \mathrm{BF})+0.5623 * \mathrm{HCW}
$$

In which, LMY is weight of the major commercial cuts in the area of Antioquia, Colombia (loin, head loin, rib, beef bacon, hand, and leg), BF is backfat thickness measured at $6 \mathrm{~cm}$ from the 
midline at the last rib in $\mathrm{mm}$, and $\mathrm{HCW}$ is hot carcass weight in $\mathrm{kg}$.

Backfat thickness (BF), loin eye area at the last rib, and LMY were determined on the right side of the carcass ${ }^{(3)}$. Longissimus dorsi muscle (LDM) sample was taken and cut into chops from medium zone to determine quality attributes such as color, $\mathrm{pH}^{(3)}$, water retention capacity (WRC), shear force (SF), and fatty acids profile. $\mathrm{pH}$ was determined $6 \mathrm{~h}$ postmortem by using a portable $\operatorname{potentiometer}^{(7)}$.

Water retention capacity (WRC) of the loin was determined by grounding a $350 \mathrm{mg}$ sample with a screen of $4.5 \mathrm{~mm}$. The sample then was taken on filter paper and covered with acetate paper, the assembly was subjected to pressure with a texturometer for $5 \mathrm{~min}$, keeping the pressure constant at $10 \mathrm{~kg}$-f. The sample then was allowed to dry for $24 \mathrm{~h}$ for analysis. The analysis of images of the loin area and WRC was performed by using the Google Sketchup 8 software (Google, Inc., Mountain View, CA, USA).

Instrumental color was measured on chops using a HunterLab MiniScan EZ Spectrophotometer (Hunter Associates Laboratory Inc., Reston, West Virginia, USA). Samples were read using illuminant D65 observer and evaluated for CIE $\left(L^{*}, a^{*}\right.$ and $\left.\mathrm{b}^{*}\right)$ color values. Cooking losses were evaluated on loin chops by weighting changes before and after cooking, and tenderness was determined on cooked samples by measuring shear force on Warner-Bratzler according to the methods described by Della Casa et al. ${ }^{(7)}$, Lammers et al. ${ }^{(2)}$, and Mendoza et al. ${ }^{(9)}$.

For economic analysis a partial budget was used as follow:

$\mathrm{C}=(\mathrm{B}+\Sigma(\operatorname{cij}(\mathrm{Yij}))) / \mathrm{X}$

In which, $\mathrm{C}$ is cost per $\mathrm{kg}$ of swine in pesos, $\mathrm{B}$ is pig cost at $20 \mathrm{~kg}, \mathrm{X}$ is body weight of pigs at the end of the experiment, $\mathrm{Y}$ is feed conversion, $\mathrm{c}$ is experiment diet cost in $\mathrm{j}$ phase, and $\mathrm{i}$ is experimental treatment in i phase.

$\mathrm{PNI}=[(\mathrm{Py} * \mathrm{Yi})-(\mathrm{Px} * \mathrm{Xi})] / \mathrm{n}$

$\mathrm{PNC}=\left[\left(\mathrm{Pz} *\left(\mathrm{Yi}^{*} \mathrm{Li}\right)\right)-(\mathrm{Px} * \mathrm{Xi})\right] / \mathrm{n}$

In which: PNI is partial net income per pig per experimental group, PNC is partial net income per pig carcasses by experimental group, $\mathrm{Py}$ is price of $\mathrm{kg}$ of live swine, $\mathrm{Y}$ is body weight of pigs at the end of the experiment, $\mathrm{Px}$ is price cumulative weighted $\mathrm{kg}$ food, $\mathrm{X}$ is amount of food consumed before the sacrifice, $\mathrm{n}$ is number of pigs for slaughter/replica, $\mathrm{i}$ is experimental treatment, $\mathrm{L}$ is lean yield (\%), and $\mathrm{Pz}$ is price of pork $(\mathrm{kg})$. The prices of raw materials used for economic analysis were set according to the local market in the savannah of Bogotá, and the purchase prices of raw materials were used for testing in Colombian pesos. The price of pork was $4458 \$ / \mathrm{kg}$ to market Bogotá in April $2011^{(14)}$.

Data were analyzed as a complete block design ${ }^{(15)}$ with a random block effect for period. When significant differences occurred, analysis was performed using the linear and quadratic polynomial effect $(\mathrm{P}<0.05)$. 


\section{Results and Discussion}

The effects of inclusion of crude glycerin from PO in commercial diets of pigs on the productive performance are summarized in Table 3. According to the results, the level of PO crude glycerin in the diet, up to $10 \%$, did not affect pig performance $(\mathrm{P}>0.05)$ or feeding cost per kilogram of live pigs $(\mathrm{P}>0.05)$.

Results in carcass quality of pigs fed different levels of crude glycerin from PO were summarized in Table 4. Dietary treatments did not affect carcass characteristics $(\mathrm{P}>0.05)$ or feeding cost to produce one kilogram of lean meat $(\mathrm{P}>0.05)$.

Results of growing, carcass characteristics, and meat quality obtained in the present study are similar to those observed with crude glycerin from soybean oil ${ }^{(2)}$. The study of Lammers et al. ${ }^{(2)}$ evaluated crude glycerin in growing pigs and described animal growth, feed intake, conversion, fat in the $10^{\text {th }}$ rib, loin area and free fat percentage showing no effects due to treatments, similarly to the results found in the present study. Contrary, in piglets, the inclusion of crude glycerin improved average daily gain in linear form, without affecting consumption and conversion ${ }^{(16)}$, similar to the results obtained with $8 \%$ glycerol in $\operatorname{diet}^{(10)}$ and growing pigs ${ }^{(8)}$.

In another study, a slight reduction in weight gain in the early stages of development of fattening pigs was noticed; however, at slaughter, there were no significant differences in the performance of the animals. Carcass characteristics were not affected by the recommended inclusion of crude glycerol up to $9 \%$ of the $\operatorname{diet}^{(3)}$, similar to the results obtained with $8 \%$ glycerol in the diet ${ }^{(10)}$. Contrary to the results observed in the present experiment, Della Casa et al. ${ }^{(7)}$ verified that $5 \%$ glycerin inclusion in the diet did not affect the performance heavy pigs (46-160 kg) at fattening; however, glycerin inclusion at $10 \%$ reduced weight gain and adversely affected feed conversion. Mendoza et al. ${ }^{(9)}$ observed there was no effect of refined glycerin on characteristics of carcass or meat quality of finishing pigs.

There was no effect $(\mathrm{P}>0.05)$ of crude glycerin from PO on the parameters of meat quality (Table 5). The findings of this study show that the inclusion of crude glycerin to a level of $10 \%$ did not affect most of the meat quality features analyzed $(\mathrm{P}>0.05)$. However, we observed an increase $(\mathrm{P}$ $<0.05)$ in the cooking losses with the increase in the level of crude glycerin from PO in the diet.

The effects of glycerin on meat quality were similar to those observed in the study of fattening heavy pigs ${ }^{(7)}$, where treatments did not affect the characteristics of meat or fat ham. The sensory responses were not very consistent to lead to any conclusions, as noted by Della Casa et al. ${ }^{(7)}$. Observations in meat quality were similar to those verified with crude glycerin derived from soybean oil, which were not affected by treatments including crude glycerin. But contrary to the present results, in that study, the $\mathrm{pH}$ of the loin increased with the inclusion of crude glycerin ${ }^{(2)}$. 
Table 3. Performance of pigs fed different levels of crude glycerin from PO during a complete cycle

\section{Crude glycerin level, $\%{ }^{1} \quad \mathrm{P}^{2}$}

\begin{tabular}{llllll} 
Item & $\mathbf{0}$ & $\mathbf{5}$ & $\mathbf{1 0}$ & L & Q \\
\hline Replicates & 4 & 4 & 4 & &
\end{tabular}

Initial weight, $\mathrm{kg}$

$23.03 \pm 1.6 \quad 23.26 \pm 1.6 \quad 22.88 \pm 1.6$

Final weight, $\mathrm{kg}$

$100.52 \pm 2.2 \quad 102.45 \pm 2.2 \quad 98.75 \pm 2.2 \quad 0.523 \quad 0.257$

$\mathrm{ADG}^{3}, \mathrm{~kg} / \mathrm{d}$

$0.849 \pm 0.02 \quad 0.867 \pm 0.02 \quad 0.828 \pm 0.02$

$0.508 \quad 0.303$

$\mathrm{ADFI}^{4}, \mathrm{~kg} / \mathrm{d}$

$2.28 \pm 0.13$

$2.46 \pm 0.13$

$2.34 \pm 0.13$

$\begin{array}{ll}0.516 & 0.099\end{array}$

Feed conversion, g/g

$2.69 \pm 0.11$

$2.84 \pm 0.11$

$2.84 \pm 0.11$

$0.244 \quad 0.444$

20 to $30 \mathrm{~kg} \mathrm{BW}$

ADG, $\mathrm{kg} / \mathrm{d}$

$0.713 \pm 0.06$

$0.803 \pm 0.06$

$0.796 \pm 0.06$

$0.370 \quad 0.544$

ADFI, $\mathrm{kg} / \mathrm{d}$

$1.19 \pm 0.06$

$1.39 \pm 0.06$

$1.29 \pm 0.06$

$\begin{array}{lll}0.287 & 0.077\end{array}$

Feed conversion, g/g

$1.68 \pm 0.12$

$1.76 \pm 0.12$

$1.66 \pm 0.12$

$0.894 \quad 0.568$

30 to $50 \mathrm{~kg}$ BW

$\mathrm{ADG}, \mathrm{kg} / \mathrm{d}$

$0.860 \pm 0.05$

$0.8723 \pm 0.05$

$\begin{array}{lll}0.891 \pm 0.05 & 0.609 & 0.952\end{array}$

ADFI, $\mathrm{kg} / \mathrm{d}$

$\begin{array}{lllll}1.95 \pm 0.05 & 2.06 \pm 0.05 & 2.03 \pm 0.05 & 0.283 & 0.284\end{array}$

Feed conversion, $\mathrm{g} / \mathrm{g}$

$2.27 \pm 0.1$

$2.38 \pm 0.1$

$2.29 \pm 0.1$

$0.852 \quad 0.270$

\section{0 to $70 \mathrm{~kg}$ BW}

$\mathrm{ADG}, \mathrm{kg} / \mathrm{d}$

$0.956 \pm 0.05$

$0.911 \pm 0.05$

$0.854 \pm 0.05$

$0.189 \quad 0.917$

ADFI, $\mathrm{kg} / \mathrm{d}$

$2.49 \pm 0.21$

$2.47 \pm 0.21$

$2.66 \pm 0.21$

0.423

0.593

Feed conversion, $\mathrm{g} / \mathrm{g}$

$2.60 \pm 0.22$

$2.69 \pm 0.22$

$3.16 \pm 0.22$

$0.084 \quad 0.448$

70 to $100 \mathrm{~kg}$ BW

ADG, $\mathrm{kg} / \mathrm{d}$

$\begin{array}{lllll}0.822 \pm 0.06 & 0.895 \pm 0.06 & 0.779 \pm 0.06 & 0.561 & 0.167\end{array}$

ADFI, $\mathrm{kg} / \mathrm{d}$

$2.73 \pm 0.07$

$3.13 \pm 0.07$

$2.76 \pm 0.07$

$0.771 \quad 0.002$

Feed conversion, $\mathrm{g} / \mathrm{g}$

$3.33 \pm 0.2$

$3.56 \pm 0.2$

$3.58 \pm 0.2$

$0.363 \quad 0.669$

Feeding cost, $\$ / \mathrm{Kg}$

BW

$2494.8 \pm 96.2 \quad 2598.8 \pm 96.2 \quad 2553.8 \pm 96.2 \quad 0.591 \quad 0.440$

\footnotetext{
${ }^{1}$ Mean \pm Standar Error (SE)

${ }^{2} \mathrm{P}=\mathrm{P}$ value for lineal $(\mathrm{L})$ and quadratic $(\mathrm{Q})$ effect

${ }^{3} \mathrm{ADG}=$ Average daily gain

${ }^{4} \mathrm{ADFI}=$ Average daily feed intake
} 
Table 4. Features of carcass quality of pigs fed different levels of crude glycerin for a complete cycle

Crude glycerin level, $\%{ }^{1} \quad \mathrm{P}^{2}$

\begin{tabular}{|c|c|c|c|c|c|}
\hline Item & $\mathbf{0}$ & 5 & 10 & $\mathbf{L}$ & Q \\
\hline Replicates & 4 & 4 & 4 & & \\
\hline $\mathrm{HCW}^{3}, \mathrm{~kg}$ & $82 \pm 6.3$ & $83 \pm 6.3$ & $81.13 \pm 6.3$ & 0.850 & 0.721 \\
\hline Carcass yield, \% & $82.2 \pm 1.7$ & $83.5 \pm 1.7$ & $83.05 \pm 1.7$ & 0.492 & 0.426 \\
\hline Backfat, mm & $14.5 \pm 1.3$ & $15.1 \pm 1.3$ & $13.4 \pm 1.3$ & 0.553 & 0.466 \\
\hline Loin area, $\mathrm{cm}^{2}$ & $49.93 \pm 4.6$ & $56.27 \pm 4.6$ & $47.3 \pm 4.6$ & 0.672 & 0.186 \\
\hline Loin depth, mm & $62.38 \pm 4.6$ & $74.24 \pm 4.6$ & $70.06 \pm 4.6$ & 0.269 & 0.189 \\
\hline Lean yield, \% & $43.87 \pm 2.5$ & $45.5 \pm 2.5$ & $45.48 \pm 2.5$ & 0.377 & 0.593 \\
\hline Lean Weight, $\mathrm{Kg}$ & $36 \pm 4.1$ & $38.1 \pm 4.1$ & $37.54 \pm 4.1$ & 0.651 & 0.651 \\
\hline Lean Cost, $\$ / \mathrm{Kg}$ & $5389 \pm 577$ & $5526 \pm 577$ & $5489 \pm 577$ & 0.858 & 0.858 \\
\hline
\end{tabular}

${ }^{1}$ Mean \pm Standar Error (SE)

${ }^{2} \mathrm{P}=\mathrm{P}$ value for lineal $(\mathrm{L})$ and quadratic $(\mathrm{Q})$ effect

${ }^{3} \mathrm{HCW}=$ Hot carcass weight

Table 5. Meat quality of pigs fed different levels of crude glycerin for a complete cycle Crude glycerin level, $\%$

\begin{tabular}{lccccc}
\multicolumn{1}{c}{ Item } & $\mathbf{0}$ & $\mathbf{5}$ & $\mathbf{1 0}$ & $\mathbf{L}$ & $\mathbf{Q}$ \\
\hline Replicates & 4 & 4 & 4 & & \\
$\mathrm{pH}$ & $5.5 \pm 0.07$ & $5.5 \pm 0.07$ & $5.4 \pm 0.07$ & 0.474 & 0.696 \\
Shear Force, kg-f & $4.9 \pm 0.8$ & $6.01 \pm 0.8$ & $5.9 \pm 0.8$ & 0.279 & 0.226 \\
WHC, mm/mm & $6.9 \pm 1.1$ & $5.68 \pm 1.1$ & $6.53 \pm 1.1$ & 0.803 & 0.433 \\
Cooking losses, \% & $25.2 \pm 0.02$ & $30.7 \pm 0.02$ & $29.9 \pm 0.02$ & 0.037 & 0.082 \\
Color & & & & & \\
$L^{*}$ & $55.84 \pm 1.9$ & $51.77 \pm 1.9$ & $52.2 \pm 1.9$ & 0.220 & 0.365 \\
$a^{*}$ & $14.3 \pm 0.7$ & $14.1 \pm 0.7$ & $14.9 \pm 0.7$ & 0.421 & 0.501 \\
$b^{*}$ & $7.0 \pm 0.497$ & $6.8 \pm 0.503$ & $6.6 \pm 0.497$ & 0.076 & 0.968 \\
\hline
\end{tabular}

${ }^{1}$ Mean \pm Standar Error (SE)

${ }^{2} \mathrm{P}=\mathrm{P}$ value for lineal $(\mathrm{L})$ and quadratic $(\mathrm{Q})$ effect

${ }^{3}$ Water Holding Capacity

The increase in cooking losses was contrary to what was previously observed: that the inclusion of 
glycerin could reduce water loss from the carcass and cooking ${ }^{(6)}$. However, more recent studies have not shown this condition ${ }^{(2,7)}$. This increase in cooking losses could be explained by hyperhydration in the tissues caused by increased consumption of glycerol, a result that is consistent with that observed in athletes ${ }^{(17)}$. Several experiments ${ }^{(2,3,7-10)}$ did not reveal effects of the inclusion of crude glycerin on lightness $(\mathrm{L} *)$, red index $(\mathrm{a} *)$, and yellow index $(\mathrm{b} *)$ of pork loins, similarly to the results of the present study.

Based on the findings of the present study, the inclusion of crude glycerin up to a level of $10 \%$ did not affect the fatty acid composition of intramuscular fat of the loin $(\mathrm{P}>0.05)$ (Table 6).

Previous studies have showed an increase in oleic acid in the backfat at the expense of linoleic and linolenic acids and consequently a reduction in the ratio polyunsaturated fatty acids (PUFA): saturated fatty acids (SA). This result could be explained by variations in the fatty acid content of the experimental diets where the PUFA were reduced to include crude glycerin from soybean oil in place of $\operatorname{corn}^{(2)}$. Contrasting results were obtained in the present study in which the level of linoleic acid was kept constant in the diet by varying inclusion levels from palm oil and full-fat soybean. Therefore, since the linolenic acid was constant within the experimental diets, the fatty acid profile of pork loin did not change due to the inclusion level of PO crude glycerin.

Table 6. Profile of long chain fatty acids in the intramuscular fat of loin from pigs fed different levels of crude glycerin for a complete cycle

Crude glycerin level, $\%{ }^{1} \quad \mathrm{P}^{2}$

\begin{tabular}{|c|c|c|c|c|c|}
\hline Item & $\mathbf{0}$ & 5 & 10 & $\mathbf{L}$ & Q \\
\hline Replicates & 4 & 4 & 4 & & \\
\hline Ether extract, \% & $9.96 \pm 2.08$ & $11.93 \pm 2.08$ & $13.37 \pm 2.08$ & 0.060 & 0.845 \\
\hline Myristic, \% & $1.4 \pm 0.08$ & $1.3 \pm 0.08$ & $1.4 \pm 0.08$ & 0.998 & 0.292 \\
\hline Palmitic, $\%$ & $25.6 \pm 0.6$ & $24.9 \pm 0.6$ & $25.5 \pm 0.6$ & 0.927 & 0.346 \\
\hline Stearic, \% & $12.1 \pm 0.9$ & $13.2 \pm 0.9$ & $12.8 \pm 0.9$ & 0.594 & 0.526 \\
\hline Oleic, $\%$ & $48.8 \pm 0.9$ & $49.6 \pm 0.9$ & $50.2 \pm 0.9$ & 0.222 & 0.978 \\
\hline Linoleic, \% & $7.9 \pm 0.7$ & $7.3 \pm 0.6$ & $5.9 \pm 0.6$ & 0.090 & 0.657 \\
\hline Saturated, \% & $39.2 \pm 1.2$ & $39.3 \pm 1.2$ & $39.8 \pm 1.2$ & 0.739 & 0.947 \\
\hline Unsaturated, \% & $57.0 \pm 1.2$ & $56.9 \pm 0.9$ & $56.2 \pm 0.9$ & 0.596 & 0.829 \\
\hline Uns/sat ${ }^{3}$ & $1.53 \pm 0.07$ & $1.47 \pm 0.06$ & $1.42 \pm 0.06$ & 0.242 & 0.969 \\
\hline
\end{tabular}

${ }^{1}$ Mean \pm Standar Error (SE)

${ }^{2} \mathrm{P}=\mathrm{P}$ value for lineal $(\mathrm{L})$ and quadratic $(\mathrm{Q})$ effect

${ }^{3}$ Unsaturated/Saturated

In piglets, the inclusion of up to $15 \%$ crude glycerin in the diet showed a linear increase in the content of PUFA and a linear reduction in the content of the saturated acids (SA). In addition, the relationship PUFA:SA increased linearly, which indicates glycerol is metabolized for glucose 
synthesis and not for the synthesis of fatty acids ${ }^{(18)}$. These results were also observed in lactating sows, where the inclusion of crude glycerin increased the lactose content in milk demonstrating a gluconeogenic effect of glycerol ${ }^{(19)}$.

According to the results of this study (Table 7), the inclusion of up to $10 \% \mathrm{PO}$ crude glycerin in the diet did not affect the economic analysis variables reviewed in this study $(\mathrm{P}>0.05)$.

The economic analyses were consistent with those performed by Carvalho et al. ${ }^{(20)}$, who observed a reduction in the cost of feed when the inclusion of crude glycerin in the diet increased. However, the results of the economic viability of including glycerin were not clear. It depends on other market variables, including, especially, the cost of corn and soybean meal. The reduction in feed costs by including crude glycerin ${ }^{(20)}$ is also one of the justifications given in another study on the inclusion of crude glycerin. Nevertheless, the impact of such inclusion on revenues and feeding costs has been reconsidered ${ }^{(3,16)}$.

Table 7. Economic analysis of the inclusion of PO crude glycerin in the diet of growing pigs during a complete cycle ${ }^{1}$

\begin{tabular}{lccccc}
\hline & \multicolumn{3}{c}{ Crude glycerin level, $\mathbf{\%}^{\mathbf{2}}$} & \multicolumn{2}{c}{$\mathbf{P}^{\mathbf{3}}$} \\
\multicolumn{1}{c}{ Item } & $\mathbf{0}$ & $\mathbf{5}$ & $\mathbf{1 0}$ & $\mathbf{L}$ & $\mathbf{Q}$ \\
\hline Replicates & 4 & 4 & 4 & & \\
$\mathrm{PNI}^{4}, \$$ & $254652 \pm 9790$ & $250719 \pm 9790$ & $247184 \pm 9790$ & 0,645 & 0,988 \\
$\mathrm{PNC}^{5}, \$$ & $286003 \pm 22639$ & $279279 \pm 22639$ & $281294 \pm 22639$ & 0,883 & 0,875 \\
\hline
\end{tabular}

\footnotetext{
${ }^{1}$ Values in Colombian pesos

${ }^{2} \mathrm{Mean} \pm$ Standar Error (SE)

${ }^{3} \mathrm{P}=\mathrm{P}$ value for lineal $(\mathrm{L})$ effect and quadratic $(\mathrm{Q})$

${ }^{4} \mathrm{PHI}=$ partial net income per pig per experimental group

${ }^{5} \mathrm{PNC}=$ partial net income per pig carcasses by experimental group
}

\section{Conclusions}

The use of crude glycerin from palm oil up to $10 \%$ in diets of growing pigs did not adversely affect pig performance, carcass characteristics, and meat quality. Therefore, crude glycerin from palm oil can be safely utilized as a source of energy for swine.

\section{References}

1. López L, Bocanegra J, Malagón-Romero D. Obtención de biodiesel por tramsesterificación de aceite de 
cocina usado. Ingeniería y Universidad. 2015; 19(1):155-172.

2. Lammers P, Kerr B, Weber T, Bregendahl K, Lonergan S, Prusa K, Ahn D, Stoffregen W, Dozier III W, Honeyman M. Growth performance, carcass characteristics, meat quality, and tissue histology of growing pigs fed crude glycerin-supplemented diets. Journal of Animal Science. 2008a; 86(11):2962-2970.

3. Berenchtein B,Costa L, Braz D. Utilização de glicerol na dieta de suínos em crescimento e terminação. Revista Brasilera de Zootecnia. 2010; 39(7):1491-1496.

4. Kerr B, Weber T, Dozier III W, Kidd M. Digestible and metabolizable energy content of crude glycerin originating from different sources in nursery pigs. Journal of Animal Science. 2009; 87(12):4042-4409.

5. Lammers P.J, Kerr B.J, Weber T.E, Dozier III W.A, Kidd M.T, Bregendahl K, Honeyman M.S. Digestible and metabolizable energy of crude glycerol for growing pigs. Journal of Animal Science. 2008b; 86(3):602608.

6. Mourot J, Aumaitre A, Mounier A, Peiniau P, François A.C. Nutritional and physiological effects of dietary glycerol in the growing pig. Consequences on fatty tissues and post mortem muscular parameters. Livestock Production Science. 1994; 38(3):237-244.

7. Della Casa G, Bochicchio D, Faeti V, Marchetto G, Poletti E, Rossi A, Garavaldi A, Panciroli A, Brogna N. Use of pure glycerol in fattening heavy pigs. Meat Science. 2009; 81(1):238-244.

8. Hansen C.F, Hernandez A, Mullan B.P, Moore K, Trezona-Murray M, King R.H, Pluske J.R. A chemical analysis of samples of crude glycerol from the production of biodiesel in Australia and the effects of feeding crude glycerol to growing- finishing pigs on performance, plasma metabolites and meat quality at slaughter. Animal Production Science. 2009; 49: 154- 161

9. Mendoza O.F, Ellis M, McKeith F.K, Gaines A.M. Metabolizable energy content of refined glycerin and its effects on growth performance, and carcass and pork quality characteristics of finishing pigs. Journal of Animal Science. 2010; 88(12):3887-3895.

10. Schieck S.J, Shurson G.C, Kerr B.J, Johnston L.J. Evaluation of glycerol, a biodiesel coproduct, in growfinish pig diets to support growth and pork quality. Journal of Animal Science. 2010; 88(12):3927-3935.

11. Dozier W. A, Kerr B. J, Branton S. L. Apparent metabolizable energy of crude glycerin originating from different sources in broiler chickens. Poultry Science. 2011, 90(11):2528-2534.

12. Araújo W, Albino L, Rostagno H, Hannas M, Luengas J, Silva F, Carvalho T, Maia, R. Farelo de girassol e suplementação de complexo enzimático em dietas para suínos em crescimento e terminação. Brazilian Journal of Veterinary Research and Animal Science. 2014; 51(1):49-59.

13. Perez M.R. Evaluación de la composición nutricional y digestibilidad aparente e ileal en perez porcinos del frijol mungo (Vigna radiata o Phaseolus aureus) con y sin tratamiento térmico. [Trabajo de grado de zootecnia]. [Palmira]: Universidad Nacional de Colombia; [Internet] 2011 [cited November 2016]. 113 p. Available from: www.bdigital.unal.edu.co/7179/1/mariadelrocioperezrubio.2012.pdf

14. ACP. Informe económico del sector porcicultor - abril de 2011. Porcicultura colombiana, [Internet] 2011 [cited November 2016]; 153:32-34. Available from: http://www.porcicol.org.co/porcicultores/images/porcicultores/revistas/153.pdf

15. Galyean M. L, Wester D. B. Comparison of multinomial and binomial proportion methods for analysis of multinomial count data. Journal of Animal Science. 2010; 88:3452-3463.

16. Groesbeck C.N, McKinney L.J, DeRouchey J.M, Tokach M.D, Goodband R.D, Dritz S.S, Nelssen J.L, Duttlinger A.W, Fahrenholz A.C, Behnke K.C. Effect of crude glycerol on pellet mill production and nursery pig growth performance. Journal of Animal Science. 2008; 86:2228-2236. 
17. Coutts, A, Reaburn P, Mummery K, Holmes M. The effect of glycerol hyperhydration on Olympic distance triathlon performance in high ambient temperatures. International journal of sport nutrition and exercise metabolism. 2002; 12:105-119

18. Papadomichelakis G, Zoidis E, Mountzouris K.C, Lippas T, Fegeros K. Glycerine kinase gene expression, nutrient digestibility and gut microbiota composition in post-weaned pigs fed diets with increasing crude glycerine levels. Animal Feed Science and Technology. 2012; 177 (3):247-252

19. Schieck S.J, Kerr B.J, Baidoo S.K, Shurson G.C, Johnston L.J. Use of crude glycerol, a biodiesel coproduct, in diets for lactating sows. Journal of Animal Science. 2010; 88 (8):2648-2656.

20. Carvalho P.L, Moreira I, Scapinello C, Piano L.M, Gallego A. y Moresco G. Glicerina bruta na alimentação de suínos na fase de crescimento e terminação. Semina: Ciências Agrárias. 2013; 34(3): 13991410 . 